Article

\title{
Genetic Evidence Confirms That the Porostomate Nudibranch Dendrodoris gunnamatta Allan, 1932 Is a Morphotype of Dendrodoris krusensternii (Gray, 1850) (Gastropoda: Nudibranchia)
}

\author{
Matt. J. Nimbs * (D) and Stephen D. A. Smith
}

check for

updates

Citation: Nimbs, M..J.; Smith, S.D.A. Genetic Evidence Confirms That the

Porostomate Nudibranch Dendrodoris gunnamatta Allan, 1932 Is a

Morphotype of Dendrodoris krusensternii (Gray, 1850) (Gastropoda: Nudibranchia). Taxonomy 2021, 1 , 152-159. https://doi.org/10.3390/ taxonomy1020012

Academic Editor: Peter Michalik

Received: 13 May 2021

Accepted: 10 June 2021

Published: 16 June 2021

Publisher's Note: MDPI stays neutral with regard to jurisdictional claims in published maps and institutional affiliations.

Copyright: (c) 2021 by the authors. Licensee MDPI, Basel, Switzerland. This article is an open access article distributed under the terms and conditions of the Creative Commons Attribution (CC BY) license (https:// creativecommons.org/licenses/by/ $4.0 /)$.
National Marine Science Centre \& Marine Ecology Research Centre, Southern Cross University, Coffs Harbour, NSW 2450, Australia; steve.smith@scu.edu.au

* Correspondence: matthew.nimbs@scu.edu.au

\begin{abstract}
Conspecificity of the morphologically-similar, sympatric nudibranch species Dendrodoris gunnamatta (Allen, 1932) and Dendrodoris krusensternii (Gray, 1850) was tested using sequences of the mitochondrial COI gene. Data analysis supports the presence of phenotypic polymorphy in $D$. krusensternii where specimens from large estuaries and embayments in central New South Wales, Australia either lack or have highly reduced sky-blue ocellae.
\end{abstract}

Keywords: Dendrodorididae; integrated taxonomy; synonymy; New South Wales; Australia

\section{Introduction}

Morphological similarity and sympatric distribution have led some workers to hypothesise that the porostomate nudibranch Dendrodoris gunnamatta Allan, 1932 is a darker phenotypic polymorph of the more widely distributed Dendrodoris krusensternii (Gray, 1850) [1]. The absence of a radula in this genus [2], which has historically been an important feature for morphologically separating species among other groups [3], has forestalled exploration of this hypothesis in the past [4].

Dendrodoris gunnamatta is a large, pustulose nudibranch, first described using material collected from Gunnamatta Bay, Port Hacking, New South Wales (NSW) [5] and considered to be endemic to south-eastern Australia. Iredale originally collected around fifty specimens, and some of these were subsequently used by Allan (1932) for the original description, which was accompanied by a colour illustration. However, this illustration was subsequently lost [5], p. 98.

Dendrodoris krusensternii is a charismatic nudibranch, characterised by the presence of large, brown and white tubercules interspersed with smooth areas that exhibit bright sky-blue spots (Figure 1A). It is widespread in the Indo-Pacific [6] and is found along the entire NSW coast, but not Lord Howe Island [7,8]. Across its range, D. krusensternii exhibits considerable morphological variation; however, the presence of sky-blue spots is consistent among all variants [9].

There remains some disagreement regarding the nomenclatural status of $D$. krusensternii, with some authors preferring to retain the name, Dendrodoris denisoni (Angas, 1864) (e.g., Gosliner et al. [6]). This may be in response to comments by Valdés \& Fahey [10] which, regarding the species illustrated by Gray, 1850, refrained from formally synonymising $D$. denisoni with D. krusensternii. Rather, they stated that this nomenclatural problem ought to be resolved as part of a larger study. Consequently, it is not the purpose of the present study to explore this matter, and the nomenclature used here follows WoRMS [1]. Therefore, we use the name D. krusensternii (Gray, 1850). 

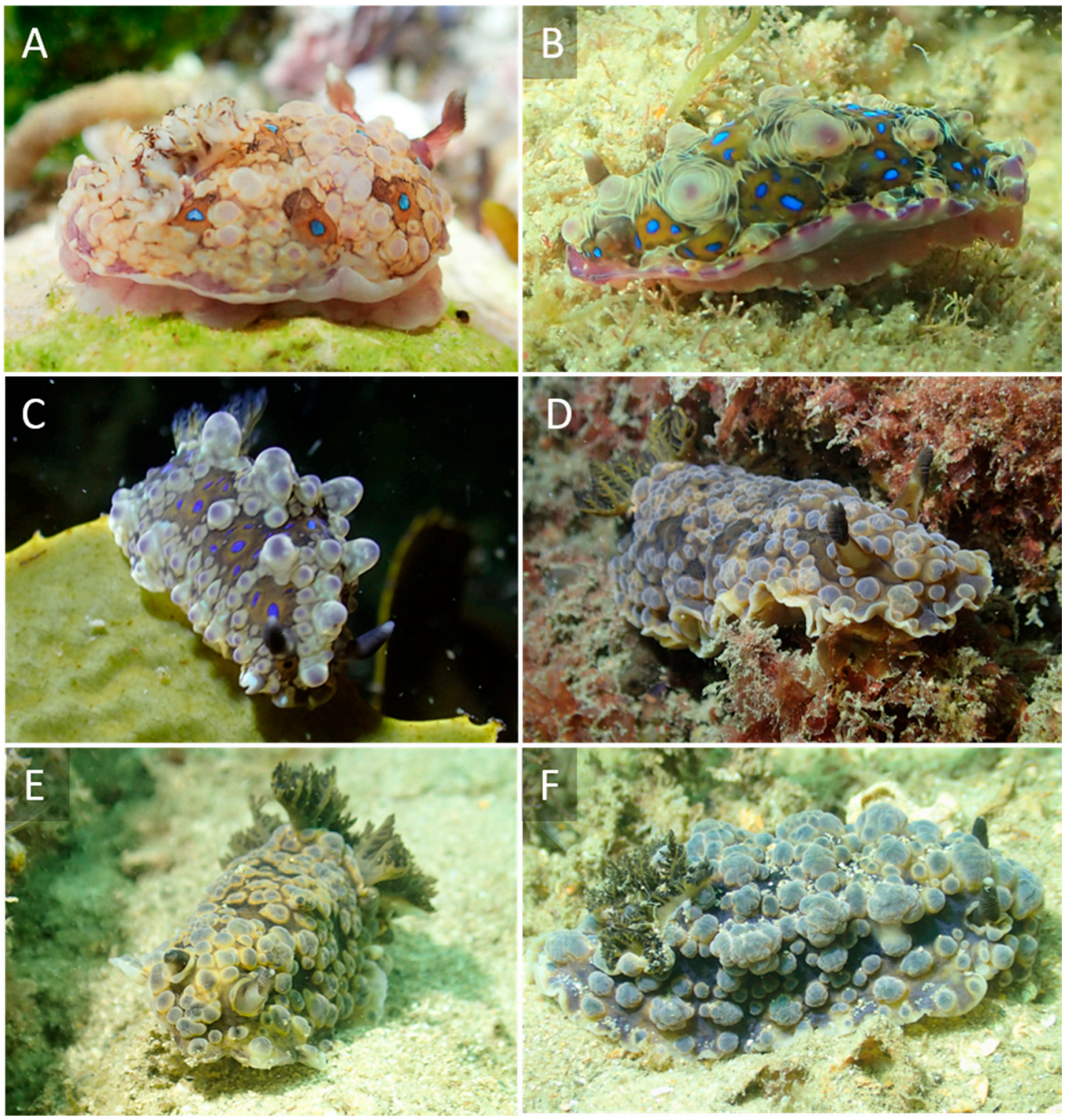

Figure 1. In situ photographs of living specimens used in this study. Dendrodoris krusensternii morphotype (A). Sawtell, NSW, Australia (NMSC105); (B). Tweed Heads, NSW, Australia (NMSC722); (C). Nelson Bay, NSW, Australia. Dendrodoris gunnamatta morphotype (D). Sydney Harbour, NSW, Australia (NMSC468); (E). Sydney Harbour, NSW, Australia (NMSC471); (F). Sydney Harbour, NSW, Australia (NMSC473). Photographs: M. Nimbs.

Angas' [11] original, colour illustration of D. krusensternii (as D. denisoni) (pl. IV, Figure 2) using specimens from Sydney, NSW, clearly shows a wide mantle with purple margins and pattern of sky-blue spots within flat, light-brown patches distributed among tuberculose ridges. Dendrodoris gunnamatta is generally larger in body size and exhibits comparatively muted colours; however, its overall morphological features vary little from D. krusensternii except for an apparent absence of sky-blue spots and often, larger dorsal tubercles. Despite these general similarities in appearance, Allan did not compare $D$. gunnamatta with D. krusensternii. As Allan's description for D. gunnamatta was based on preserved specimens in which colour was most likely lost, we agree with Rudman [3] that there remains insufficient morphological detail to conclusively synonymise these taxa but that molecular data may assist in resolving this question. 


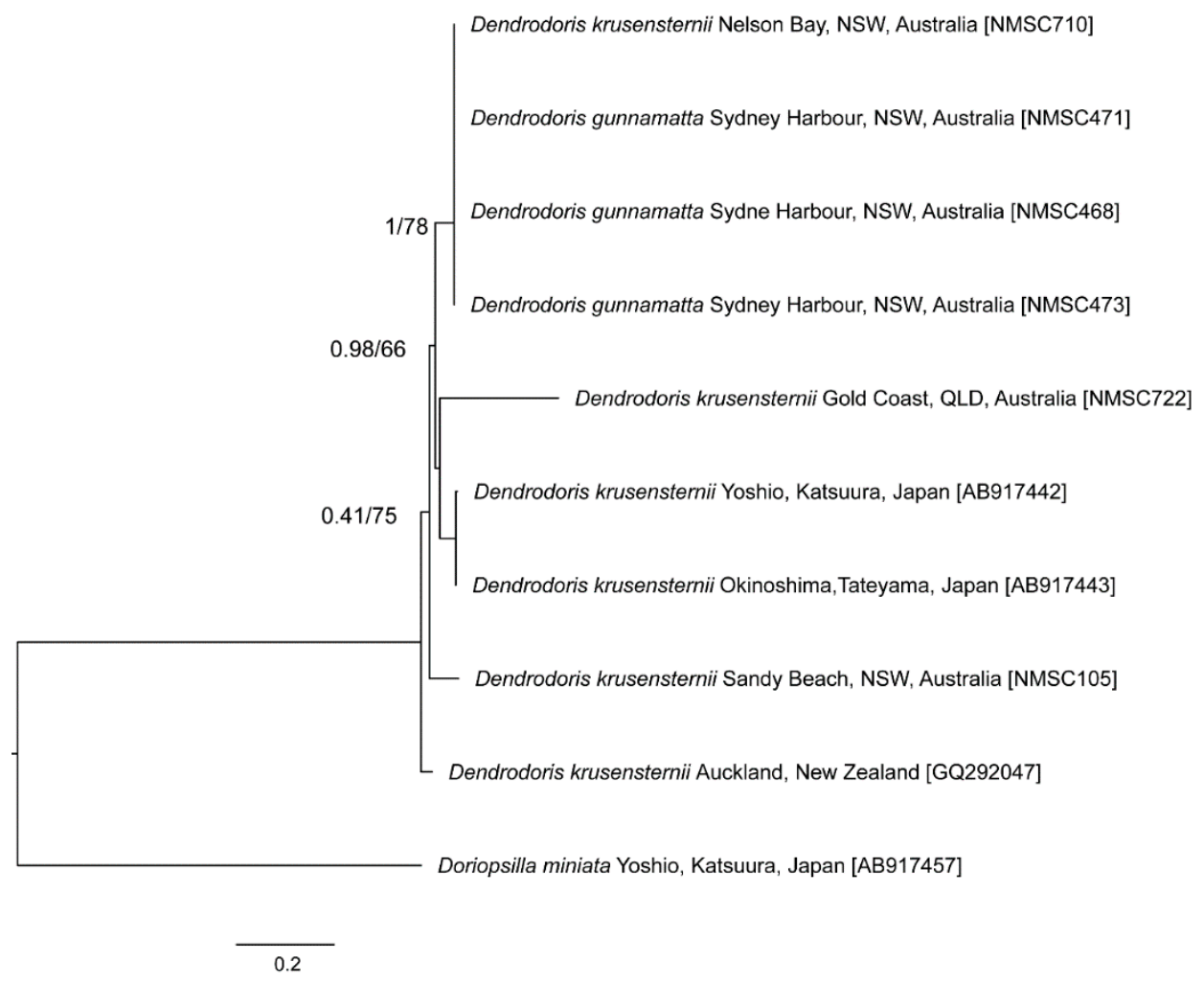

Figure 2. Molecular phylogeny of Dendrodoris krusensternii rooted with Doriopsilla miniata. Topology and branch lengths from maximum likelihood (ML) analysis of COI sequences. Branch support values branches are approximate Bayes values (left) and ML bootstrap (right).

Contemporary observations, associated with broad-scale surveys of coastal habitats in sub-tropical and warm-temperate waters of Australia's east coast $[9,12,13]$ appeared to support the hypothesis that D. gunnamatta and D. krusensternii are synonyms, with evidence of a gradation of colour patterns and the suggestion of ecomorphs, with records of D. gunnamatta primarily confined to sheltered embayments (Jervis Bay, Sydney Harbour, Nelson Bay).

The purpose of the present study was to test this hypothesis using an integrated taxonomic approach based on a combination of molecular techniques and morphological observations of living specimens. Given its utility for discrimination at the species level $[2,14,15]$, we used a fragment of the protein-coding mitochondrial Cytochrome oxidase subunit I (COI) gene to test for conspecificity. Additionally, we provide these data for use in future exploration of species-level relationships among the Dendrodorididae.

\section{Materials and Methods}

\subsection{Source of Material}

One specimen identified as D. krusensternii was collected by the authors from each of three different locations in NSW as incidental collections whilst undertaking other fieldwork (Table 1) (Figure 1A-C). Three specimens identified as D. gunnamatta (based on an absence of blue spots) were collected by the authors using SCUBA at $3 \mathrm{~m}$ on sea grass habitat at Clifton Gardens, Sydney Harbour, NSW, Australia (Table 1) (Figure 1D-F). In all cases, animals were narcotised in $7 \% \mathrm{MgCl}_{2} /$ seawater solution and then preserved in 95\% ethanol. Specimens are held at Southern Cross University's National Marine Science Centre (Table 1). 
Table 1. Details of specimens and GenBank retrieved sequences used in this study.

\begin{tabular}{cccc}
\hline Species & Locality & Voucher Number & $\begin{array}{c}\text { GenBank } \\
\text { Accession }\end{array}$ \\
\hline \multirow{5}{*}{ D. krusensternii } & Sawtell, NSW, Australia & NMSC105 & MZ373329 \\
& Yoshio, Katsuura, Japan & TY64 & AB917442 \\
& Okinoshima, Tateyama, Japan & TY82 & AB917443 \\
& Auckland, New Zealand & & GQ292047 \\
& Tweed Heads, NSW, Australia & NMSC722 & MZ373328 \\
& Nelson Bay, NSW, Australia & NMSC710 & MZ373324 \\
\hline \multirow{3}{*}{ D. gunnamatta } & Sydney Harbour, NSW, Australia & NMSC471 & MZ373326 \\
& Sydney Harbour, NSW, Australia & NMSC468 & MZ373325 \\
& Sydney Harbour, NSW, Australia & NMSC473 & MZ373327 \\
\hline Do. miniata & Yoshio, Katsuura, Japan & TY65 & AB917457 \\
\hline
\end{tabular}

\subsection{Molecular Methods}

Approximately $30 \mathrm{mg}$ of foot tissue from each specimen was sent to the University of Otago, Dunedin, New Zealand for DNA extraction, PCR, and sequencing. Each sample was rinsed in distilled water to remove any ethanol and placed in a 5\% Chelex 100 [16] solution, which was incubated overnight at $65^{\circ} \mathrm{C}$. Following brief vortexing, the solution was boiled for $10 \mathrm{~min}$ and then centrifuged at $15,000 \times g$ for $10 \mathrm{~min}$. The DNA in the supernatant was used in subsequent PCR amplifications.

Regions of COI were PCR-amplified from the DNA following the procedure of Donald et al. [17]. Annealing temperatures of $50{ }^{\circ} \mathrm{C}$ were used for amplification. The universal invertebrate COI primer LCO1490 (5'-GGTCAACAAATCATAAAGATATTGG-3') HCO2198 (5'-TAAACTTCAGGGTGACCAAAAAATCA-3') [18] was used to amplify COI. The PCR products were separated from excess primers and oligonucleotides in High Pure PCR Purification Columns (Roche). Purified DNA was quantified using agarose gel electrophoresis and subsequently sent to the Allan Wilson Centre Genome Sequencing Service for sequencing in an ABI3730 automated sequencer. Sequences were de novo assembled using Sequencher 3.1.1 [19] and edited by eye.

Consensus sequences were then exported into Geneious [20] with additional data retrieved from GenBank [21] (Table 1), where they were aligned using the MAFFT plugin [22], using default settings. Primers were trimmed from the alignment. Data quality checks were carried out with MEGABLAST [23] and protein translation. Doriopsilla miniata Alder \& Hancock, 1864 was used to root the tree for analysis, based on Hirose et al. [4].

A maximum likelihood (ML) phylogenetic tree based on the MAFFT alignment was produced by W-IQ-Tree [24] using default settings. W-IQ-Tree incorporates ModelTest [25], which selected the $\mathrm{HKY}+\mathrm{F}+\mathrm{I}$ as the best-fit model, scored according to Bayesian information criterion $(\mathrm{BIC})$, which is automatically applied $(\mathrm{BIC}=3574.3367$, weight $\mathrm{BIC}+0.7486)$. Trees were visualised using iTol [26]. Within and between-species distances (p-distances) were calculated using MEGA V7.0.26 [27].

\subsection{Photographic Methods}

Prior to collection and preservation, in situ photographs were taken of living specimens using a housed Olympus TG 6 digital camera with an iTorch at $25 \%$ power (Figure 1 ). Some images from observations made by citizen scientists at other locations were taken using equipment that is unknown. Images were post-processed in Adobe Lightroom to adjust exposure and to create magnified insets provided in some figures.

\section{Results}

PCR amplification and sequencing yielded 658bp of COI. MegaBLAST searches of the NCBI database identified best matches for all novel sequences generated by this study to COI sequence data of D. krusensternii. 
The phylogenetic reconstruction based on maximum likelihood recovered a single well-supported clade (BS = 75). Sequences from specimens identified as D. gunnamatta clustered with those identified as D. krusensternii within this clade (Figure 2). The maximum intraspecific distance based on uncorrected p-distances was 0.3613 (mean $=0.0783$ ) for $D$. krusensternii and 0.0000 (mean $=0.0000$ ) for D. gunnamatta whereas the minimum interspecific distance between the two was 0.0625 (mean $=0.0755)$. Thus, as the genetic divergence between the two putative taxa was less than the genetic divergence within $D$. krusensterniii, conspecificity was supported (Table 2). Sequences from the three $D$. gunnamatta specimens and one D. krusensternii specimen from Nelson Bay were identical, forming a single haplotype.

Table 2. Minimum interspecific and maximum intraspecific distances using uncorrected p-distances. Intraspecific distances in bold, (mean distances in parentheses).

\begin{tabular}{ccc}
\hline \multicolumn{3}{c}{ Distance between and within Species } \\
\hline & D. krusensternii & D. gunnamatta \\
\hline D. krusensternii & $\mathbf{0 . 3 6 1 3 ( 0 . 0 7 8 3 )}$ & \\
D. gunnamatta & $0.0625(0.0755)$ & $\mathbf{0 . 0 0 0 0 ( 0 . 0 0 0 0 )}$ \\
\hline
\end{tabular}

\section{Discussion}

The molecular data provided here support the hypothesis proposed by Rudman [3] that "Dendrodoris gunnamatta ... is probably a colour form of the brightly coloured Dendrodoris denisoni [D. krusensternii] ...". Without other morphological characters, the absence of a radula has been problematic when attempting to separate cryptic species among the porostomate sea slugs. Additionally, the absence of sky-blue spots surrounded by a brown ring in D. gunnamatta has been primarily responsible for its retention as a separate species from D. krusensternii. Given that Allan (1932) used preserved specimens for the original description, it is probable that if some specimens did exhibit even small blue spots (Figure 3F,G). Therefore, they are likely to have been rendered invisible as an artefact of preservation and not apparent to Allan at the time.

Dendrodoris krusensternii is found along most of the NSW coast and exhibits considerable variation in colour across that range. Whilst the colourful 'krusensternii' form can be found along the length of the coast, specimens of the dark 'gunnamatta' morphotype are found only in large embayments in central and southern NSW (Figure 3).

Both morphotypes may co-occur in some locations and intermediates may also be found. For example, at Nelson Bay specimens may range from the brightly coloured ' $k r u s e n-$ sternii' form, through an intermediate form with fewer blue-spots to the dark 'gunnamatta' morphotype (Figure 3). Occasionally, variants may be observed feeding on the same food source (Figure 4).

The Dendrodorididae can generally be identified using external morphological characters. The shallow water species Dendrodoris nigra (Stimpson, 1855), Dendrodoris arborescens (Collingwood, 1881), and Dendrodoris fumata (Rüppell \& Leuckart, 1830), each of which can range from black to orange-yellow, were once considered to be a single polychromatic species- $D$. nigra. Careful morphological study revealed the presence of multiple species [28,29] and a later molecular analysis confirmed these as separate taxa [4]. Molecular analyses have also been used to explore colour variability in the chromodorid genus Felimare Ev.Marcus \& Er. Marcus, 1967 [30]. Originally thought to comprise four separate but variable species, the Atlantic taxa Felimare clenchi (Russell, 1935) and Felimare binza (Ev.Marcus \& Er. Marcus, 1963) were each found to exhibit eight colour forms [30]. Dendrodoris gunnamatta has received little scientific attention since its description, possibly due to its very restricted range and infrequency of observation. 


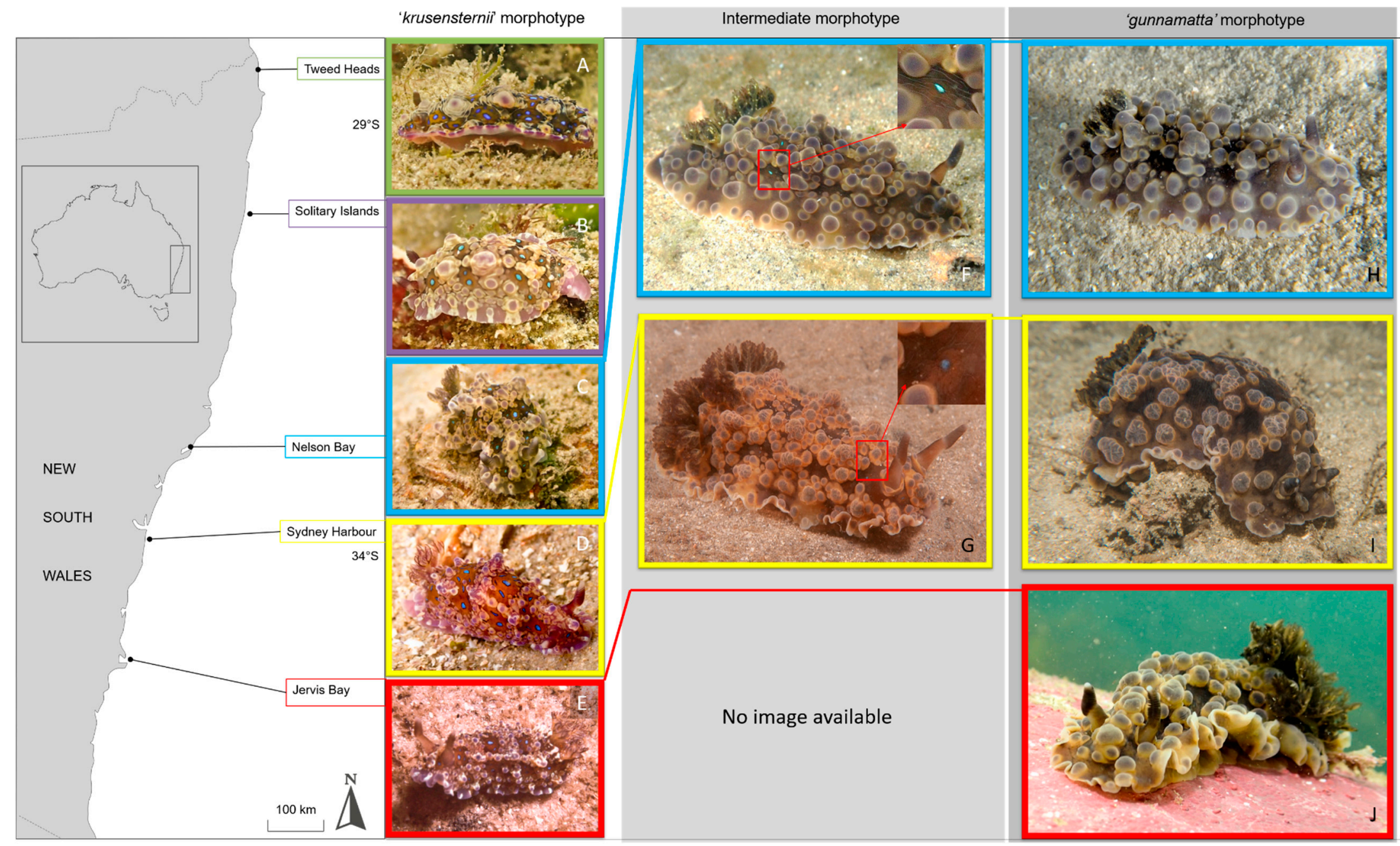

Figure 3. Distribution of D. krusensternii in NSW. The 'krusensternii' morphotype: (A) Tweed Heads (green); (B) Solitary Islands (purple); (C) Nelson Bay (blue); (D) Sydney Harbour (yellow); (E) Jervis Bay (red). Intermediate morphotype: (F) Nelson Bay; (G) Sydney Harbour. The 'gunnamatta' morphotype: (H) Nelson Bay; (G) Sydney Harbour; (H) Jervis Bay. Photos: (A-C,J) Matt Nimbs, (E) Eldon Ball, (F) John Sear, (G) Eric Schlogl, (H,I) Stephen Smith. Note that we were unable to source an image of the intermediate morphotype from Jervis Bay. 


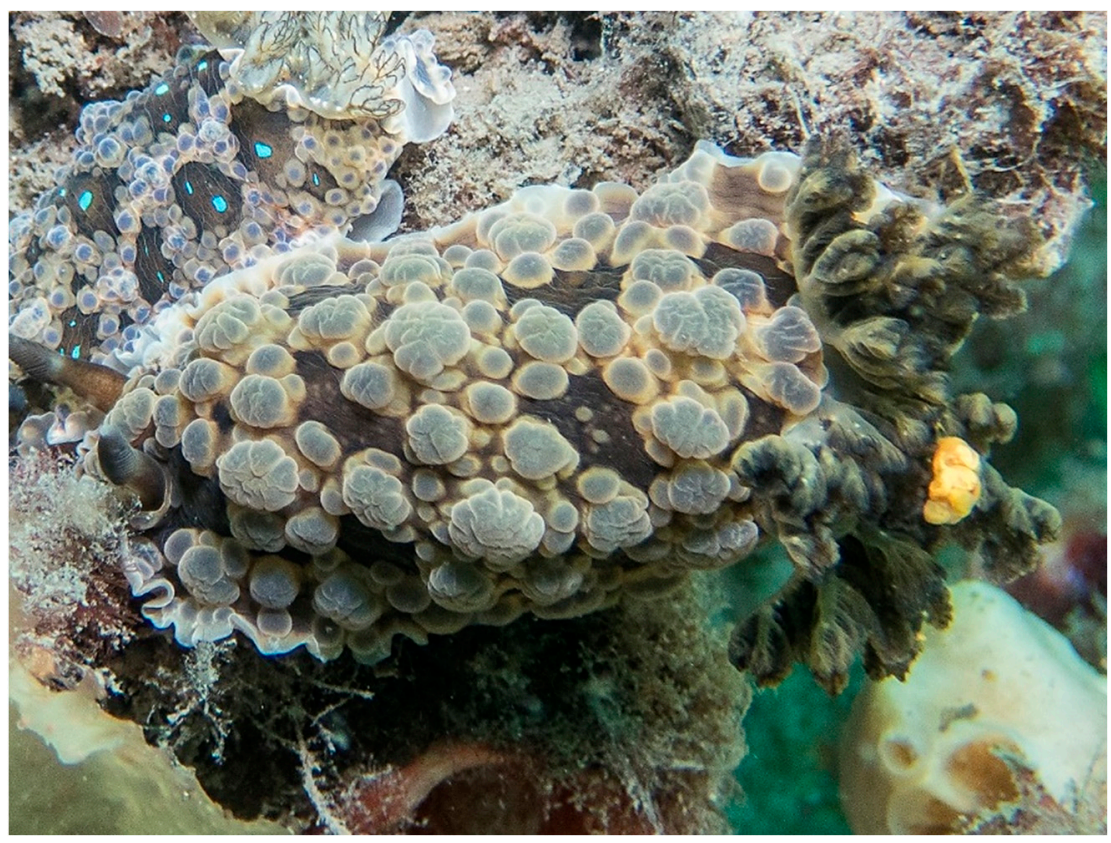

Figure 4. Two Dendrodoris krusensternii morphotypes feeding on the same food source. Top left, 'krusensternii' morphotype, and centre, 'gunnamatta' morphotype. Photo: Steve Smith.

Integrated taxonomic methods that use a combination of independent lines of evidence are now commonly used to delimit species. This approach, which uses a range of discriminatory characters, provides strong support for taxonomic decisions. In most cases, integrated taxonomic methods are used to separate species within cryptic complexes resulting in increased species diversity [31,32]. However, in this paper, these methods have been used to identify morphological variation within a single species that resulted in their historical description as separate species.

Author Contributions: Conceptualisation, methodology, validation, formal analysis, resources, writing, project administration: M.J.N. and S.D.A.S. Both authors have read and agreed to the published version of the manuscript.

Funding: This research was funded by Southern Cross University Marine Ecology Research Centre.

Data Availability Statement: The data presented in this study will be openly available in GenBank at https:/ / www.ncbi.nlm.nih.gov/nuccore.

Acknowledgments: Our thanks are due to Mandy Beasley, Kris Cooling, Nicola Fraser (Southern Cross University), Marty Kennedy, Hamish Spencer (University of Otago) for their assistance and John Sear, Eric Schlogl and Eldon Ball for permission to use photographs. We are also grateful for feedback from three anonymous reviewers that was used to improve the manuscript.

Conflicts of Interest: The authors declare no conflict of interest.

\section{References}

1. MolluscaBase. Dendrodoris krusensternii (Gray, 1850). Available online: http://www.marinespecies.org/aphia.php?p=taxdetails\& $\mathrm{id}=550448$ (accessed on 5 April 2021).

2. Hirose, M.; Hirose, E.; Kiyomoto, M. Identification of five species of Dendrodoris (Mollusca: Nudibranchia) from Japan, using DNA barcode and larval characters. Mar. Biol. 2015, 45, 769-780. [CrossRef]

3. Rudman, W.B. Re: Dendrodoris denisoni or D. gunnamatta. Available online: http://www.seaslugforum.net/message/22773 (accessed on 5 April 2021).

4. Thompson, T.E. Biology of Opisthobranch Molluscs; Ray Society: London, UK, 1976.

5. Allan, J.K. A new genus and species of sea-slug, and two new species of sea-hares from Australia. Rec. Aust. Mus. 1932, 18, 314-320. [CrossRef]

6. Gosliner, T.M.; Valdés, Á.; Behrens, D.W. Nudibranch and Sea Slug Identification: Indo-Pacific; New World Publications: Jacksonville, FL, USA, 2015. 
7. Nimbs, M.J.; Hutton, I.; Davis, T.R.; Larkin, M.F.; Smith, S.D.A. The heterobranch sea slugs of Lord Howe Island, NSW, Australia (Mollusca: Gastropoda). Proc. Roy. Soc. Vic. 2020, 132, 12-41. [CrossRef]

8. Nimbs, M.J.; Smith, S.D.A. An illustrated inventory of the sea slugs of New South Wales, Australia (Gastropoda: Heterobranchia). Proc. Roy. Soc. Vic. 2017, 128, 44-113. [CrossRef]

9. Rudman, W.B. Dendrodoris denisoni (Angas, 1864). Available online: http://www.seaslugforum.net/find/denddeni (accessed on 5 April 2021).

10. Valdés, Á.; Fahey, S.J. Dorid nudibranchs described by J. E. Gray in M. E. Gray, 1842-1857 (Mollusca: Opisthobranchia). Rec. West. Aust. Mus. Suppl. 2006, 69, 95-102. [CrossRef]

11. Angas, G.F. Description D'espèces Nouvelles Appartenant À Plusieurs Genres de Mollusques Nudibranches des Environs de Port-Jackson (Nouvelle-Galles du Sud): Accompagnée de Dessins Faits D'après Nature. J. Conchyliol. 1864, 12, 43-70.

12. Nimbs, M.J.; Smith, S.D.A. Beyond Capricornia: Tropical sea slugs (Gastropoda, Heterobranchia) extend their distributions into the Tasman Sea. Diversity 2018, 10, 99. [CrossRef]

13. Smith, S.D.A.; Davis, T.R. Slugging it out for science: Volunteers provide valuable data on the diversity and distribution of heterobranch sea slugs. Moll. Res. 2019, 39, 214-223. [CrossRef]

14. Dayrat, B.; Conrad, M.; Balayan, S.; White, T.R.; Albrecht, C.; Golding, R.; de Frias Martins, A.M. Phylogenetic relationships and evolution of pulmonate gastropods (Mollusca): New insights from increased taxon sampling. Mol. Phylogenet. Evol. 2011, 59, 425-437. [CrossRef]

15. Lindgren, A.R. Molecular inference of phylogenetic relationships among Decapodiformes (Mollusca: Cephalopoda) with special focus on the squid order Oegopsida. Mol. Phylogenet. Evol. 2010, 56, 77-90. [CrossRef]

16. Walsh, P.S.; Metzger, D.A.; Higuchi, R. Chelex 100 as a medium for simple extraction of DNA for PCR-based typing from forensic material. Biotechniques 1991, 10, 506-513. [CrossRef]

17. Donald, K.M.; Kennedy, M.; Spencer, H.G. Cladogenesis as the result of long-distance rafting events in South Pacific topshells (Gastropoda, Trochidae). Evolution 2005, 59, 1701-1711.

18. Folmer, O.; Black, M.; Hoeh, W.; Lutz, R.; Vrijenhoek, R. DNA primers for amplification of mitochondrial cytochrome c oxidase subunit I from diverse metazoan invertebrates. Mol. Mar. Bio. Biotechnol. 1994, 3, 294-299.

19. Nishimura, D. Sequencher 3.1.1. Biotech Softw. Internet Rep. 2000, 1, 24-30. [CrossRef]

20. Kearse, M.; Moir, R.; Wilson, A.; Stones-Havas, S.; Cheung, M.; Sturrock, S.; Duran, C. Geneious Basic: An integrated and extendable desktop software platform for the organization and analysis of sequence data. Bioinformatics 2012, 28, 1647-1649. [CrossRef]

21. Clark, K.; Karsch-Mizrachi, I.; Lipman, D.J.; Ostell, J.; Sayers, E.W. GenBank. Nucleic Acids Res. 2016, 44, D67-D72. [CrossRef] [PubMed]

22. Katoh, K.; Standley, D.M. MAFFT multiple sequence alignment software version 7: Improvements in performance and usability. Mol. Bio. Evol. 2013, 30, 772-780. [CrossRef]

23. Johnson, M.; Zaretskaya, I.; Raytselis, Y.; Merezhuk, Y.; McGinnis, S.; Madden, T.L. NCBI BLAST: A better web interface. Nucleic Acids Res. 2008, 36 (Suppl. 2), W5-W9. [CrossRef] [PubMed]

24. Minh, B.Q.; Nguyen, M.A.T.; von Haeseler, A. Ultrafast approximation for phylogenetic bootstrap. Mol. Biol. Evol. 2013, 30, 1188-1195. [CrossRef] [PubMed]

25. Kalyaanamoorthy, S.; Minh, B.; Wong, T.K.; von Haeseler, A.; Jermiin, L.S. ModelFinder: Fast model selection for accurate phylogenetic estimates. Nat. Methods 2017, 14, 587-589. [CrossRef] [PubMed]

26. Letunic, I.; Bork, P. Interactive Tree Of Life (iTOL): An online tool for phylogenetic tree display and annotation. Bioinformatics 2007, 23, 127-128. [CrossRef]

27. Kumar, S.; Stecher, G.; Tamura, K. MEGA7: Molecular evolutionary genetics analysis version 7.0 for bigger datasets. Mol. Biol. Evol. 2016, 33, 1870-1874. [CrossRef]

28. Brodie, G.D.; Calado, G. Dendrodoris arborescens (Collingwood, 1881)(Mollusca: Nudibranchia): Larval characteristics reveal a masked porostome species. Rec. West. Aust. Mus. Suppl. 2006, 69, 119-126. [CrossRef]

29. Brodie, G.D.; Willan, R.C.; Collins, J.D. Taxonomy and occurrence of Dendrodoris nigra and Dendrodoris fumata (Nudibranchia: Dendrodorididae) in the Indo-West Pacific region. J. Molluscan Stud. 1997, 63, 407-423. [CrossRef]

30. Padula, V.; Bahia, J.; Stöger, I.; Camacho-García, Y.; Malaquias, M.A.E.; Cervera, J.L.; Schrödl, M. A test of color-based taxonomy in nudibranchs: Molecular phylogeny and species delimitation of the Felimida clenchi (Mollusca: Chromodorididae) species complex. Mol. Phylogenet. Evol. 2016, 103, 215-229. [CrossRef] [PubMed]

31. Golestani, H.; Crocetta, F.; Padula, V.; Camacho-García, Y.; Langeneck, J.; Poursanidis, D.; Pola, M.; Yokeş, M.B.; Cervera, J.L.; Jung, D.-W.; et al. The little Aplysia coming of age: From one species to a complex of species complexes in Aplysia parvula (Mollusca: Gastropoda: Heterobranchia). Zool. J. Linn. Soc. 2019, 187, 279-330. [CrossRef]

32. Nimbs, M.J.; Wilson, N.G. Saved by the shell: Molecular analysis detects the cryptic sea hare, Aplysia concava G. B. Sowerby I, 1833 (Mollusca: Heterobranchia: Aplysiidae), from Oceania, with a redescription. Taxonomy 2021, 1, 48-59. [CrossRef] 